\title{
The influence of water migration of microelements on the ecological soil condition of Ukraine
}

\author{
Orest Furdychko, Lidiya Moklyachuk*, Tetiana Yegorova \\ Institute of Agroecology and Environmental Management, National Academy of Agricultural Sciences of Ukraine
}

\section{A B S T R A C T}

It is shown the role of natural geochemical processes of migration of trace elements for forming of food chains. Calculations of the coefficients of water migration $\mathrm{Co}, \mathrm{Zn}, \mathrm{Mo}, \mathrm{Mn}, \mathrm{Cu}$ and ionic strength of waters of small rivers in Ukraine were made. Intensity of water migration of chemical elements were assessed by coefficient $(\mathrm{Kx})$, complex mobility of certain groups of chemical elements in aqueous solutions was evaluated by the coefficient of ionic strength of solutions (CIS). It is shown that spatial imbalance of quantity of microelements $\mathrm{Zn}, \mathrm{Mo}, \mathrm{Co}, \mathrm{Mn}, \mathrm{Cu}$ in soils Ukraine related with water mobility of these elements and the degree of metamorphization of natural waters.

Keywords: Biocenosis; Microelements Migration; Surface water

\section{INTRODUCTION}

Microelements migration in the links of biogeochemical food chain from rocks to agrocenosis is complicated process and a have not been studied enough (KabataPendias, 2011). Several natural connections are considered by various sciences and different methodological approaches - hydrogeology, biogeochemistry, biology, ecology (Makarova, 2006; Shestopalov, et al., 2007). At the same time these processes have active influence on the agroecological condition of the territories and effectiveness of melioration measures (Furdychko and Stadnik, 2012). The intensity of the water migration of chemical elements determines the mass of microelements that are involved to the biological cycle, affecting the chemical composition of agricultural production and public health (Faybishenko, B. et al., 2014).

Today there are many known geographic patterns of disease that have been correlated with properties of soils or waters, or even aerosol particles. It has been difficult to demonstrate cause-effect relationships for many correlations, and efforts to relate total concentration of a metal contaminant to toxic impact have proven difficult (Davies et al., 2005; Koshliakov O. E. et al., 2014). Homeostatic processes of a living organism are multi-vector and dynamic. However, biophils are delivered to the plants only in solutions (Perelman, 1989). The chemical composition of natural solutions (soil solutions, underground water and surface water, precipitation) is subordinated the law of natural zonation that reflects the natural hydrochemical zonation, landscapes zonation and biogeochemical chains. As a result, concentration of chemical elements in natural water and their movability are the primary factors of their distribution in all types of local biocenosis. Biogenic concentration can reach an excessive level and create biogeochemical anomalies, i.e. not technogenic but natural (Carrillo-Gonzalez et al., 2006). On the contrary, scattering of the separate chemical elements in water are the factors of their low content in biocenoses, and for technogenic landscapes as an indicator of unmanifested technogenic pollution.

Our researches are devoted to the processes of water physic-chemical migration of $\mathrm{Co}, \mathrm{Zn}, \mathrm{Mo}, \mathrm{Mn}, \mathrm{Cu}$ and its impact on soil condition and agrocenosis in Ukraine.

Ecological features of biogeochemical food chains of certain essential microelements in different climatic zones of Ukraine were studied at the level of the «soil - agrocenosis» links by Vlasyuk and Kowalskiy during the 1970s. Ecological balance of microelements

\footnotetext{
* Corresponding author:

Lidiya Moklyachuk, Institute of Agroecology and Environmental Management, National Academy of Agricultural Sciences of Ukraine. E-mail: moklyachuk@ukr.net
}

Received: 09 Feburary 2014; Revised: 03 January 2015; Accepted: 14 January 2015; Published Online: 29 May 2015 
in biogeochemical chains is determined by the threshold limits that were determined by Kowalskiy (1991) using the methods of geochemical ecology. The indicator of vital necessity of any element is a bell-shaped dependence line between concentration of this element and the response of a living organism. Low income of the element into organism causes harm to its functioning as a result the decrease of ferments activity. With the increase of the dose to the level of biotic concentration, a response reaction of the organism increases, reaching the standards. Further dose increasing causes an activity decrease in the functioning of organism as a consequence of the toxic effects of excess element. As deficiency of (lack of) biogenic element, and also its excess are able to do damage to living organism (Ivanov, 1994). The model of process of chemical elements movability in the hypergenesis zone was the first time outlined in the 20 s of the 20th century in the writings of Fersman (1977) and Polynov (1956). In the works of Perelman (1975), migration of chemical elements, as a process that leads to their concentration and scattering in the space and time, came into practical implementation. Scientist identified the main forms of movement of chemical elements as 4 kinds of geochemical migration - mechanical, biogeneous, technogenic and physicochemical (air and water) (Perelman, 1975).

Water physic-chemical migration is caused mainly by the processes of dissolution, crystallization and sorption in hydrological and hydrogeological natural systems (Moklyachuk, et al., 2013). According to Perelman (1975) it is subordinated to physical and chemical laws, and has crucial significance in the geochemical cycle and redistribution of chemical elements in the landscapes.

Alloway (2008) has studied transitional d-block elements $\mathrm{Zn}, \mathrm{Co}, \mathrm{Cu}, \mathrm{Mo}, \mathrm{Mn}$ that have high biological activity. He summarized the soil conditions which most commonly give rise to deficiencies of zinc in crops can include one or more of the following: low total zinc concentrations (such as sandy soils); low $\mathrm{pH}$, highly weathered parent materials with low total zinc contents (e.g. tropical soils); high calcium carbonate content (calcareous soils); neutral or alkaline $\mathrm{pH}$ (as in heavily limed soils or calcareous soils); high salt concentrations (saline soils); peat and muck (organic soils); high phosphate status, prolonged water logging or flooding (paddy rice soils); high magnesium and/or bicarbonate concentrations in soils or irrigation water (Alloway, 2008).

The aim of our study was to identify relationships between process water migration trace elements and their content in soils of agricultural landscapes.

\section{MATERIALS AND METHODS}

For quantitative assessment of intensity and direction of water migration $\mathrm{Co}, \mathrm{Zn}, \mathrm{Mo}, \mathrm{Mn}, \mathrm{Cu}$ we used monoelemental and complex parameters. Mono-element intensity of water migration of chemical elements is estimated by the coefficient of water migration $(\mathrm{Kx})$, introduced by Perelman (1975). Kx characterizes the mobility of chemical elements in the system «water-rock» and is the ratio of the element concentration in water to the concentration in rock and total mineralization (Perelman, 1975).

$\mathrm{Kx}=\left(\mathrm{m}_{\mathrm{x}}^{*} 100\right) /\left(\mathrm{a}^{*} \mathrm{n}_{\mathrm{x}}\right)$,

where $\mathrm{m}_{\mathrm{x}}$ - concentration of chemical element $\mathrm{X}$ in water $(\mathrm{mg} / \mathrm{l}), \mathrm{a}-$ mineralization of water $(\mathrm{mg} / \mathrm{l}), \mathrm{n}_{\mathrm{x}}-$ content of element $\mathrm{X}$ in the rock (\%).

According to the estimates of $\mathrm{Kx}$ for continental waters of the world performed by Perelman (1975), water migrants are divided into very movable $(\mathrm{Kx}=10 \mathrm{n} \div 100 \mathrm{n})$, easily movable $(\mathrm{Kx}=\mathrm{n} \div 10 \mathrm{n})$, movable $(\mathrm{Kx}=0, \mathrm{n} \div \mathrm{n})$ and slightly movable/inert $(\mathrm{Kx}<0, \mathrm{n})$. Given intervals $\mathrm{Kx}$ can be considered as global norms of water migration intensity of certain groups of chemical elements. For example, Mo and $\mathrm{Zn}$ belong to the group of easily movable, and $\mathrm{Mn}, \mathrm{Co}$ and $\mathrm{Cu}$ are movable water migrants. For regional trends determination of microelements migration in water we determined the ratio between the coefficients of water migration that are calculated through the territory of Ukraine and global standards for continental waters. Exceeding of $\mathrm{Kx}$ global assessments indicates intensification of water migration of chemical element and becomes geochemical factor for its excessive accumulation in biogeochemical chains. On the contrary, reduced water mobility of microelements indicates weakened water migration, reveals the complication of processes of biogenic migration and is a factor of low concentration of these elements in food chains.

Complex mobility of certain groups of chemical elements in water solutions is determined by ionic strength of solutions $(\mu)$, which was estimated by the coefficient of ionic strength of solutions (CIS) introduced by Belyakova et al. (1985). CIS is calculated as the ratio of the content $(\mathrm{mEq} / \mathrm{L})$ of the anions of the strong acids $\left(\mathrm{Cl}^{-}, \mathrm{SO}_{4}^{2-}\right.$, $\left.\mathrm{NO}_{3}^{-}\right)$to anions of weak acids $\left(\mathrm{HCO}_{3}^{-}, \mathrm{CO}_{3}^{2-}\right)$ in water. The value of the coefficient is coordinated with the ionic strength of the natural solution and regulates as the intensity of the microelements transition from rock and soil into waters as well as a stability of water physicchemical migration. In general, with CIS increasing and therefore the ionic strength of the natural solutions, water mobility and intensity of chemical elements transition from 
rock to water solution are reduced. According to the CIS levels, there are 4 main types of waters: not metamorphic (CIS $\leq 0,5)$, primary metamorphic (CIS $=0,5 \div 4$ ), average metamorphic (CIS $=4 \div 60$ ), high metamorphic (CIS $\geq 60$ ) (Belyakova et al., 1985). With increasing the degree of water metamorphic of certain groups and essential elements lose their ability to participate in biogeochemical cycles.

In order to assess the regional distribution of $\mathrm{Co}, \mathrm{Zn}$, $\mathrm{Mo}, \mathrm{Mn}, \mathrm{Cu}$ in soils of Ukraine, we have calculated the ratio between their content and global soil Clarke (Clarke concentration) by Bowen (1979). Ecological analysis of parameters of water migration $\mathrm{Co}, \mathrm{Zn}, \mathrm{Mo}, \mathrm{Mn}, \mathrm{Cu}$ was conducted for agricultural and soil zones of Ukraine: Ukrainian Polissya; Forest-steppe; Steppe and Dry steppe, as well as for areas of ecological and geochemical provinces that have microelement disbalance in biogeochemical chains and increased morbidity among children of certain microelementosis.

The studies used experimental data of geological, ecological and hydrochemical mapping of Ukraine that were conducted for the period 1981-1992. Data analysis was performed using Microsoft Excel, 2010.

\section{RESULTS AND DISCUSSION}

Investigated water migration of chemical elements that belong to the transitional d-block elements that have high biological activity ( $\mathrm{Zn}, \mathrm{Co}, \mathrm{Cr}, \mathrm{Mo}, \mathrm{Mn})$. Their main function for biocenosis is to form centers of ferments and hormones, stimulation of haematopoiesis and metabolic processes enhancement. Co, Mn, Zn, Mo are necessary in organism for protein, carbohydrate and fat metabolism. $\mathrm{Mn}, \mathrm{Co}, \mathrm{Cu}$ take part in the protein synthesis, $\mathrm{Co}, \mathrm{Cu}, \mathrm{Mn}$, $\mathrm{Zn}$ in hematogenesis and respiration processes (Kowalskiy, 1991; Ivanov, 1994).

Calculations of water migration coefficients $(\mathrm{Kx})$ of $\mathrm{Co}, \mathrm{Zn}, \mathrm{Mo}, \mathrm{Mn}, \mathrm{Cu}$; ionic strength coefficients of surface waters (CIS) and Clarke soil concentration was performed based on a database of hydro-lithochemical and geoecological surveys in the territory Ukraine for 2422 conjugate observation points of water - bottom sediments of small rivers in Ukraine and 3000 soil samples (Yegorova, 2001; 2009). By the results of the calculations of $\mathrm{Kx}$ it is revealed that water mobility fluctuations of considered micronutrients are greater than the global estimates (Table 1).

Meanwhile, the average statistical estimates of mobility of $\mathrm{Co}, \mathrm{Mo}, \mathrm{Mn}, \mathrm{Cu}(\mathrm{Kx}=0,1,2,5)$ correspond only to the lower level of global norms $(\mathrm{Kx}=0.1-1)$. Decreased mobility is revealed for $\mathrm{Zn}(\mathrm{Kx}=0.2-0.8)$, which is manifested the least in Polissya. Specified characteristics of elements water solutions, especially $\mathrm{Zn}$, may cause suppression of their biogenic accumulation in agrocenoses, even under the condition of their increased concentration in rock and soil.

Unlike spatially indistinguishable $\mathrm{pH}$ values, coefficient of water ionic strength highlights the natural hydrochemical zonation of the territory of Ukraine (Table 2).

Generalized values of the coefficients of ionic strength (CIS) reflect hydrochemical features of surface waters and in some way are subordinated to agricultural soil zonation of Ukraine. Not-metamorphized freshwater or brackish hydrocarbonate calcium water with $\mathrm{pH}$ from 4.3 to 8.5 with average statistical estimates of CIS = $0.3-0.4$ are dominating on the territory of Ukrainian Polissya and Forest-steppe. The highest ionizing and carbon dioxide aggressiveness is typical for such waters. Such hydrochemical conditions are the most favorable for transition of soil cations into solutions, their water migration and transition in vegetation complexes. These agro-soil zones are the territories of stable concordance between the chemical composition of soils and soil solutions, and that is the reason for biogeochemical chains «soil-agrocenosis» to be interdependent: the lack or excess of microelements in soil determines an appropriate disbalance in agricultural crops.

On the territory of Steppe and Dry Steppe of Ukraine the water of average metamorphization is distributed. These waters are predominantly brackish, salt calcium magnesium sulfate and chloride-sulfate with $\mathrm{pH}$ from 6.2 to 7.8 with average statistical estimates of CIS $=6.1-8.8$. Such waters have acidic aggressiveness. Such hydrochemical conditions are favorable for the transition of soil cations in solutions, but only certain microelements (eg, $\mathrm{Pb}, \mathrm{Ba}$, $\mathrm{Sr}$ ) have steady water migration and appropriate transition to vegetation. Energetic features of the investigated microelements promote their precipitation and the formation of secondary supergene concentrations in soils and rock. Because of these reasons, agro-soil zones of Ukrainian Steppe are the territories of discrepancy between the chemical composition of soil and soil solutions. Most of essential elements weaken the biogenic migration in the «soil-agrocenosis» system due to their physical and chemical concentration within the limits of abiogenical components of agricultural landscapes - soils and pedogenic rock. Therefore, soil biogeochemical chains «soil-agrocenosis» are not interdependent: the excess of examined microelements in soils may not cause their excessive concentration in agricultural crops. 
Table 1: Statistical parameters of microelements coefficients of water migration in agro-soil zones of Ukraine

\begin{tabular}{|c|c|c|c|c|c|c|c|c|c|c|c|c|c|c|c|}
\hline \multirow[t]{3}{*}{$\begin{array}{l}\text { Agricultural soil } \\
\text { zones of Ukraine }\end{array}$} & \multicolumn{9}{|c|}{$\begin{array}{l}\text { Statistical parameters of the } \\
\mathrm{Kx} \text { distribution }(\mathrm{Zn}, \mathrm{Mo}, \mathrm{Co})\end{array}$} & \multicolumn{6}{|c|}{$\begin{array}{l}\text { Statistical parameters of the } \\
\mathrm{Kx} \text { distribution }(\mathrm{Mn}, \mathrm{Cu})\end{array}$} \\
\hline & \multicolumn{3}{|c|}{$K_{\mathrm{zn}}$} & \multicolumn{3}{|c|}{$\mathbf{K}_{\mathrm{Mo}}$} & \multicolumn{3}{|c|}{$\mathbf{K}_{\mathrm{co}}$} & \multicolumn{3}{|c|}{$\mathbf{K}_{\mathrm{Mn}}$} & \multicolumn{3}{|c|}{$\mathbf{K}_{\mathrm{cu}}$} \\
\hline & $\min$ & $\max$ & mean & Min & $\max$ & mean & $\min$ & $\max$ & $\min$ & $\min$ & $\max$ & mean & $\min$ & $\max$ & $\min$ \\
\hline Ukrainian Polissya & 0.8 & 125 & 0.8 & 0.1 & 10 & 1.4 & 0.1 & 12.5 & 0.4 & 0.01 & 60 & 0.5 & 0.1 & 20 & 0.6 \\
\hline Forest-steppe & 0.03 & 40 & 0.2 & 0.1 & 20 & 1.03 & 0.03 & 3.8 & 0.2 & 0.01 & 30 & 0.1 & 0.01 & 20 & 0.5 \\
\hline Steppe & 0.01 & 13.3 & 0.2 & 0.03 & 66.7 & 1.3 & 0.03 & 7.5 & 0.1 & 0.01 & 20 & 0.1 & 0.01 & 0.6 & 0.2 \\
\hline Dry steppe & 0.01 & 187.5 & 0.5 & 0.3 & 60 & 2.5 & 0.03 & 12.5 & 0.3 & 0.01 & 40 & 0.1 & 0.03 & 1.7 & 0.3 \\
\hline $\begin{array}{l}\text { Kx Global standards } \\
\text { (Perelman, 1975) }\end{array}$ & $1-30$ & & & $1-30$ & & & $0.1-5$ & & & $0.1-5$ & & & $0.1-5$ & & \\
\hline
\end{tabular}

Table 2: Statistical parameters of ionic strength coefficients and acid-base indicators of surface waters in agro-soil zones in Ukraine

\begin{tabular}{|c|c|c|c|c|c|c|c|}
\hline \multirow{2}{*}{$\begin{array}{l}\text { Agro-soil zones } \\
\text { in Ukraine }\end{array}$} & \multicolumn{4}{|l|}{ CIS } & \multicolumn{3}{|c|}{ pH } \\
\hline & Predominant type of water by CIS & $\min$ & $\max$ & mean & $\min$ & $\max$ & mean \\
\hline $\begin{array}{l}\text { Ukrainian } \\
\text { Polissya }\end{array}$ & Non-metamorphized $(70 \%)^{\mathrm{a}}$ & 0.1 & 2.2 & 0.3 & 6.0 & 8.5 & 7.2 \\
\hline Forest-steppe & Non-metamorphized and little metamorphized $(98 \%)^{a}$ & 0.1 & 12.3 & 0.4 & 4.3 & 8.5 & 7.2 \\
\hline Steppe & Averagely metamorphized $(66 \%)^{\mathrm{a}}$ & 0.1 & 56.1 & 6.1 & 6.2 & 7.8 & 7.2 \\
\hline Dry steppe & Averagely metamorphized $(76 \%)^{a}$ & 0.3 & 59.0 & 8.8 & 6.2 & 7.8 & 7.1 \\
\hline
\end{tabular}

Note: apercentage of samples of prevailing types of water

Investigated peculiarities of water microelements migration in the territory of Ukraine not only have great influence on the nature of biogeochemical food chains, but also determine ecological condition of soil and agricultural products. Studied distribution of Co, $\mathrm{Zn}, \mathrm{Mo}, \mathrm{Mn}, \mathrm{Cu}$ in the soils of Ukraine indicates that for the majority of samples, their concentration is not significantly higher the global soil Clarks developed by Bowen (1979) (Table 3).

Ecological imbalance of $\mathrm{Zn}, \mathrm{Mo}, \mathrm{Co}, \mathrm{Mn}, \mathrm{Cu}$ in the soils of Ukraine highlights the distribution of ecological and geochemical provinces that were identified and described by Yegorova (2003) in accordance with the researches of interconnected landscape-ecological and biogeochemical researches (Fig. 1).

The spread of ecological and geochemical provinces with shortage of $\mathrm{Mo}, \mathrm{Co}, \mathrm{Mn}$ and excess of $\mathrm{Zn}, \mathrm{Cu}$ enhances the imbalance of micronutrients in biogeochemical food chains. As the consequence, development of appropriate phytopathology of agricultural crops, and hypo-microelementosis and hyper-microelementosis of animals and people take place.

For example, on the majority of territories of Ukraine with the lack of Mo, Co, Mn, enhanced morbidity, respectively, glomerulonephritis, anemia, and diabetes among children (Yegorova, 2001, 2003). Considering the peculiarities of water migration of listed microelements, probability of hazardous ecological effects from their shortage and an excess in the soils for agrocenoses and livestock is the highest within the boundaries of Ukrainian Polissya and Steppe.

\section{CONCLUSION}

The analysis of water mobility of essential microelements provided an opportunity to link the lower and upper levels of biogeochemical food chains through the process of water physic-chemical migration of microelements and chemistry of natural waters. Obtained results prove that the relatively low water mobility of microelements on the territory of Ukraine is a regional factor of low concentration of $\mathrm{Mo}, \mathrm{Co}, \mathrm{Mn}$ in soils and crop production.

The development of phytopathologies and endemic diseases in the population has a higher probability in Ukrainian Polissya and Forest-steppe, where waters are mainly not-metamorphic and have low ionic strength. Lack of microelements in the soil surface with significant increase of their water mobility indicates the activation of processes of qualitative degradation of soils, which occur with different intensity in the Dry Steppe and in Ukrainian Polissya.

\section{Author contributions}

O. F. planned the study and wrote the article. L. M. provided the idea about influence of the natural geochemical processes of migration of trace elements for forming of food chains and corrected the article. T. Y. collected the data, analyzed and interpreted the experimental data, searched literature and wrote the article. 
Table 3: Distribution of microelements in the soils of Ukrainian agrolandscapes with different degree of water metamorphization.

\begin{tabular}{|c|c|c|c|c|c|}
\hline \multirow[t]{2}{*}{ Type of water according to CIS } & \multicolumn{5}{|c|}{ The percentage of samples with a lack of trace elements in soil (\%) } \\
\hline & $\mathrm{Zn}$ & Mo & Co & Mn & $\mathrm{Cu}$ \\
\hline $\begin{array}{l}\text { Not-metamorphic } \\
\mathrm{CIS} \leq 0,5)\end{array}$ & 94 & 99 & 100 & 99 & 85 \\
\hline $\begin{array}{l}\text { Primary metamorphic } \\
\mathrm{CIS}=0,5-4\end{array}$ & 96 & 95 & 96 & 100 & 86 \\
\hline $\begin{array}{l}\text { Averagely and high metamorphic }(66 \%) \\
\mathrm{CIS}=4-60\end{array}$ & 97 & 97 & 98 & 99 & 84 \\
\hline \multicolumn{6}{|l|}{ Standards for levels of trace elements in soil (mg/kg) } \\
\hline $\begin{array}{l}\text { Minimally sufficient levels of trace elements in soils } \\
\text { (Kowalskiy, 1991) }\end{array}$ & 120 & 1,8 & 12 & 1500 & 45 \\
\hline Soil Clarks, mg/kg (Bowen, 1979) & 90 & 1,2 & 8 & 1000 & 30 \\
\hline
\end{tabular}

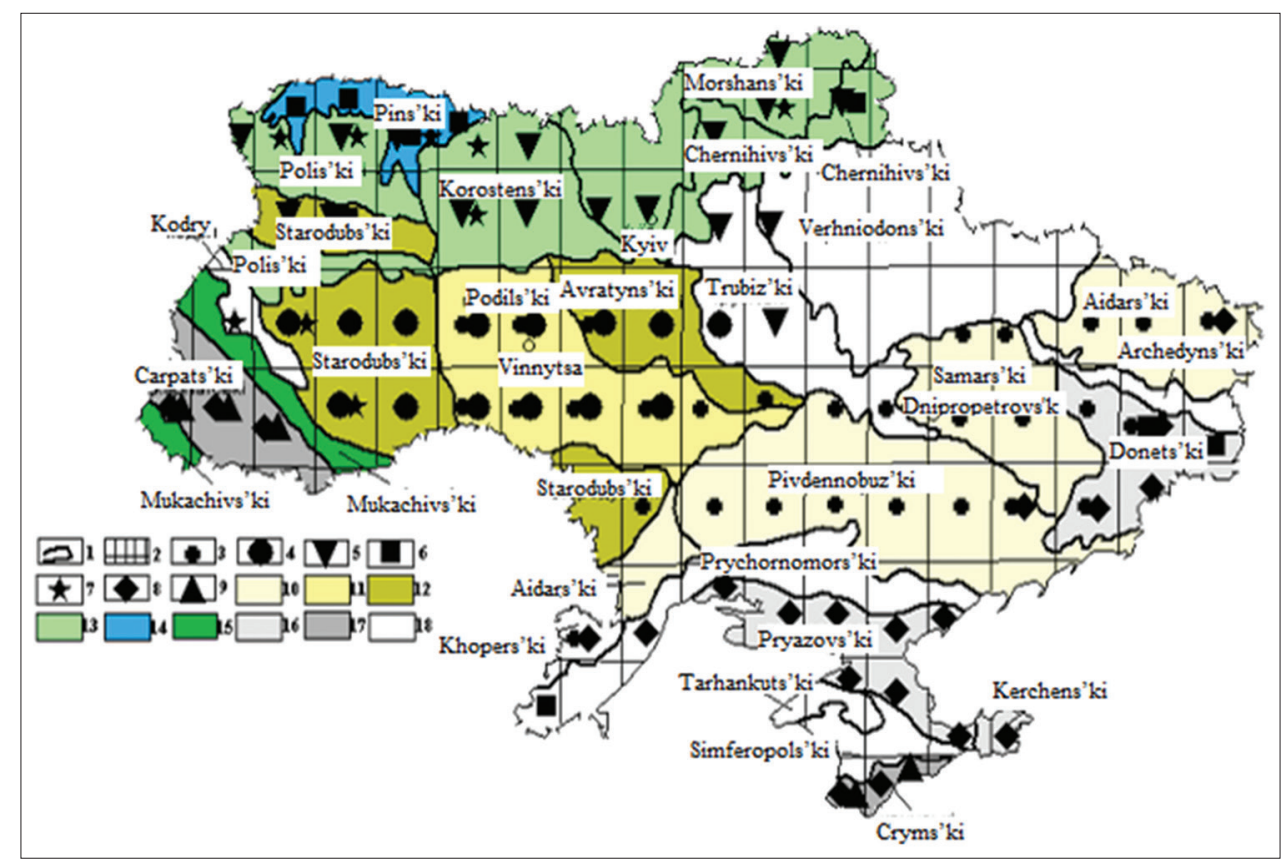

Fig 1. Scheme of distribution of ecological and geochemical provinces of $\mathrm{Zn}, \mathrm{Mo}, \mathrm{Co}, \mathrm{Mn}$ and $\mathrm{Cu}$ in Ukraine: 1 - boundary and title of regional geochemical landscape; 2 - limits of territorial squares. Distribution of ecological and geochemical provinces within the limits of territorial squares: 3 - Zn-Mo (lack of Mo and an excess of Zn); 4-Mo (lack of Mo); 5 - Mo, Co (lack of Mo, Co) 6 - Zn-Mo, Co (lack of Mo, Co) 7 - Co, Mn (lack of $\mathrm{Co}, \mathrm{Mn}$ ); 8 - Zn (excess of Zn); 9 - Zn, Cu (excess of $\mathrm{Zn}, \mathrm{Cu}$ ). The spread of ecological and geochemical provinces within the limits of regional geochemical landscapes: 10 - Zn-Mo; 11 - complex of Zn-Mo and Mo; 12 - Mo; 13 - Mo, Co; 14 - complex of Zn-Mo, Co and Co, Mn; 15 - Co, $\mathrm{Mn} ; 16$ - Zn; 17 - complex of Zn and Zn, Cu; 18 - landscapes of lacking concentration of ecological and geochemical provinces.

\section{REFERENCES}

Alloway, B. J. 2008. Zinc in Soils and Crop Nutrition. $2^{\text {nd }}$ ed. Paris, IZA and IFA Brussels.

Belyakova, A. V., N. P. Zuev and E. E. Nikitina. 1985. Hydrogeochemical studies (supergene zone). In: Principles and Methods of Estimation of Ore-Bearing Geological Formations. Nedra, Leningrad.

Bowen, H. J. M. 1979. Environment Chemistry of the Elements. N. Y: Academic Press.

Carrillo-Gonzalez, R., J. Simunek, S. Sauve and D. Adriano. 2006. Mechanisms and pathways of trace element mobility in soils. Adv. Agron. 91: 111-178.

Davies, B. E., C. Bowman, T. C. Davies and O. Selinus. 2005. Medical geology: Perspectives and prospects. In: Selinus, O., (Ed.). Essentials of Medical Geology. Amsterdam, Elsevier. Pp. 1-14.
Faybishenko, B., T. J. Nicholson, V. Shestopalov, A. Bohuslavsky and V. Bublias. (Eds.). 2014. Groundwater Vulnerability: Chernobyl Nuclear Disaster. USA, American Geophysical Union.

Fersman, A. 1977. Essays on the mineralogy and geochemistry. Moscow, Nauka. Pp. 73-94.

Furdychko, O. I. and A. P. Stadnik. 2012. Fundamentals of management of agricultural landscapes of Ukraine. Kyiv, Nauka.

Ivanov, V. V. 1994. In: Burenkova, E. K., (Ed.). Environmental Geochemistry of Elements. Vol. 4-5. Moscow, Nedra.

Kabata-Pendias, A. Trace Elements in Soils and Plants. $4^{\text {th }}$ ed. US, CRC Press.

Koshliakov, O. E., O. V. Dyniak and I. E. Koshliakova. 2014. Natural security (vulnerability) of groundwater used for drinking water supply in Kiev. Bull. ONU: Geogr. Geol. Sci. 19: 269-273.

Kowalskiy, V. V. 1991. Geochemical ecology. A new direction in the study of the variability of metabolism under the influence 
of excess or lack of trace elements. In: Proceedings of the Biogeochemical Laboratory. Moscow, Nauka. 22(S): 5-23.

Makarova, Y. U. 2006. Ecological-biogeochemical studies of agrophytocenosis of samara region. Bull Samara State Uni 7: 108-117.

Moklyachuk, L., O. Furdycko, V. Strelko, S. Melnichuk, V. Shynkarenko, V. Lokhanska, V. Trykhlib, I. Maletina, N. Iliuk and B. Nikitina. 2013. The use of natural zeolites impregnated with zinc and copper ammoniates as carriers of micronutrients in growing vegetables. Emir. J. Food Agric. 25: 980-985.

Perelman, A. I. 1975. Landscape Geochemistry. Moscow, Higher School.

Perelman, A. I. 1989. Geochemistry, Moscow, Higher School.
Polynov, V. V. 1956. Geochemistry of Landscapes. Selected Works. Moscow, Publisher USSR Academy of Sciences. Pp. 477-486.

Shestopalov, V. M., A. S. Boguslavskiy and V. N. Bublyas. 2007. Groundwater Protectability and Vulnerability Assessment with Account of Fast Migration Zones. Alt-Art, Kyiv, Institute of Geological Sciences of NAN of Ukraine.

Yegorova, T. 2001. Regional eco-geochemical provinces of Ukraine. In: Geology of the Twentieth Century. Future Development and Prospects. Kyiv, Znannya. Pp. 138-145.

Yegorova, T. 2003. Expected Co, Mo, Mn, Zn in biogeochemical subregions of Ukraine. In: Reports of the National Academy of Sciences. 11: 201-206.

Yegorova, T. 2009. Landscape Ecology of Ukraine. Ukraine, Publisher P. P. Zavoleyko, Kamenetz-Podolsk. 